\title{
Trade Openness and Real Investment: Is there Asymmetric Cointegration Relationship? Evidence from Jordan
}

\author{
Alaaeddin Al-Tarawneh ${ }^{1}$ \\ ${ }^{1}$ Business Economics Department, the School of Business, The University of Jordan, Jordan \\ Correspondence: Alaaeddin Al-Tarawneh, Business Economics Department, the School of Business, The \\ University of Jordan, Jordan. E-mail: a.altarawneh@ju.edu.jo
}

Received: May 7, 2016

doi:10.5539/ijef.v8n8p237
Accepted: June 16, 2016

Online Published: July 25, 2016

\begin{abstract}
The paper attempts to test the long-run asymmetric equilibrium relationships between real investment and trade openness. Using Jordanian data, over the period 1976 to 2014, the study has failed to reject the null hypothesis of no cointegration with threshold at a conventional level of significance among variables. Therefore, cannot find evidence of asymmetry in the relationship between real investment and trade openness.
\end{abstract}

Keywords: real investment, trade openness, asymmetric cointegration relationship, Jordan

\section{Introduction}

A considerable literature is developed considers different specifications of investigating a long-run relationships among macroeconomic variables. Most of these studies assume that this potential relationship may be represented as a symmetric linear combination of non-stationary stochastic regressors. Only a very few papers have paid attention to the case of nonlinear dynamics in the variables, where the series under consideration might be linked in an asymmetric relationship. Hence, asymmetric behavior in economic variables has attracted attention in time series analysis through employing specific tests to investigate whether series adjust asymmetrically towards its long-run equilibrium value.

This paper contributes by examining the cointegrating relationship between real investment and trade openness using asymmetric cointegration test adopted by Enders and Siklos (2001). The remainder of this paper continues as follows. Section 2 summarises the main literature. Section 3 introduces the methodology used, and section 4 shows the empirical results. Section 5 concludes.

\section{Review of Literature}

A number of studies consider the relationship between trade openness and the level of investment using a variety of econometric techniques, Including cross section and time series analysis and using samples of groups of countries. Some of these studies employed causality analysis on trade-finance nexus. Many empirical studies have used a number of variables, suggested by the theory, in an attempt to describe the determinants of investment in both developed and developing countries. Shafik (1992) provided a comprehensive survey of the empirical work on estimating investment function before 1990s on developing countries. She used an error-correction model and co-integration to test Egyptian data for a private investment function that takes into account some features of developing countries. She found that a number of variables, including mark ups, internal financing, demand and the cost of investment, are the main determinants of the private investment in Egypt. Sun (1998), using data on China for the period 1953 to 1995, found that the long-run investment function can be characterized by co-movements of real fixed investment, grain output per capita, and energy supply per capita.

In their article, du Toit and Moolman (2004) found that, in South Africa, investment depends on the interest rate (the user cost of capital), international position, and domestic and foreign financial constraints. Ismihan et al. (2005) used data from Turkey covering the period 1963 to 1999. The main findings they made were that capital formation and growth are seriously affected by the macroeconomic instability of the Turkish economy. Anoruo et al. (2007) estimated a neoclassical model of investment for Bangladesh covering the time period 1973 to 2004. They found that there is an equilibrium relationship between the investment-output ratio, real output, and real interest rate. 
Heim (2008) identified seven major variables that have a significant effect on the investment demand in the US economy for the period 1960 to 2000. These variables are the crowd out problem, depreciation, growth rate of GDP, interest rate, growth in stock values, exchange rate changes, and company profitability. A study by Oladipo (2011) employed cointegration techniques to examine the impact of trade liberalization (openness) on long run economic growth. The empirical results, obtained from a quarterly data on Mexico, showed that investment play a significant role in determining the economic growth along with the trade openness in Mexico. The study has highlighted the interrelationship between trade liberalization, investment, human capital, and growth. The researcher found all these variables are statistically cointegrated.

In a previous work (Al-Tarawneh \& Al-Assaf, 2014) investigated the relationship between trade openness and real investment in Jordan. Findings provided strong evidence on the presence of a long-run stable investment function. However, the results did not provide any information whether this relationship is symmetric or asymmetric.

\section{Empirical Model}

In this paper, following Alassaf (2014), we extend the cointegration analysis on the linkages between trade openness and real investment used in a previous empirical work by employing the Enders and Siklos (2001) approach to test whether real investment respond asymmetrically to trade openness shocks. We examine whether rises in trade openness indicator slow down real investment by more or less than a rise in trade openness. In order to distinguish positive and negative effects of the error obtained from the cointegration regression. Asymmetric cointegration comes from the analysis of multivariate combinations arising from the decomposition of the series into positive and negative values of its cumulative sums (Lardic \& Mignon, 2008).

According to Cook (2006), testing for a potential asymmetric cointegration extends the analysis in further directions to allow for a possibility that other standard cointegration tests may fail to detect an underlying cointegration relationship and therefore, the threshold autoregressive and momentum-threshold cointegration tests are applied to investigate the hypothesis that the cointegration relationship between real investment indicator and trade openness is of an asymmetric form which splits the speed of adjustments into two parts based on the direction of the equilibrium error.

For the purpose of the present paper, we first estimate the potential long-run relationships among real investment and trade openness along with other explanatory variables (Note 1 ).

$$
L R I_{t}=\beta_{0}+\beta_{1} L T O_{t}+\beta_{i, 2} L X_{i t}+\varepsilon_{i t}
$$

Where $L R I$ represents real investment at time $(t), L T O$ : Trade openness Indicator which is measured by (Exports + Imports) divided by GDP, $L X$ : represents other explanatory variables used in the literature that might affect real investment, and include real GDP (Y), real Credit (RC), and user cost of capital (UCC). All variables are expressed in logarithms. $\varepsilon$ : is the error term. All data series is obtained from the Annual Report of the Central Bank of Jordan, various issues, except for UCC calculated by other, and covering the period 1976-2014.

Testing for standard cointegration using the Engle-Granger two-step procedure (the E-G) requires that obtained residual from equation (1) to be tested for a unit root, and then the ECM for the impact of trade openness on real investment can be constructed as follows:

$$
\Delta L R I_{t}=\alpha_{0}+\sum_{j=1}^{p} \alpha_{1} \Delta L R I_{t-j}+\sum_{j=1}^{p} \alpha_{2} \Delta L T O_{t-j}+\sum_{j=1}^{p} \alpha_{i, 3} \Delta L X_{i, t-j}+\alpha_{i 4} \hat{\varepsilon}_{i t-1}+\mathrm{u}_{i t}
$$

Following Enders and Siklos (2001) and Enders and Granger (1998), the standard E-G cointegration test can be expanded to test for the presence of asymmetric cointegration. Given a number of series as it is shown in Equation 1, in the first step, a cointegration regression is estimated using OLS to obtain the long-run equilibrium relationship between real investment indicator $\left(L R I_{i}\right)$, trade openness $\left(L T O_{i}\right)$, and other variables $\left(L X_{i}\right)$, and then we look at the potential cointegration relationship through examining the stationarity properties of the residuals $\left(\hat{\varepsilon}_{i t}\right)$.

Enders and Siklos (2001) employ the following equation to test for the stationarity of $\hat{\varepsilon}_{i t}$,

$$
\Delta \hat{\varepsilon}_{i, t}=I_{t} \rho_{1} \hat{\varepsilon}_{i, t-1}+\left(1-I_{t}\right) \rho_{2} \hat{\varepsilon}_{i, t-1}+\sum_{i=1}^{k} \gamma_{i} \Delta \hat{\varepsilon}_{i, t-i}+u_{i, t}
$$

Where $\rho_{1}, \rho_{2}$, and $\gamma_{i}$ are coefficients to be estimated; $u_{i, t}$ is a white noise disturbance; $k$ is the lag length; $I_{t}$ is the Heaviside indicator function, and Enders and Siklos (2001) consider two specifications for this function based on the level $\left(\hat{\varepsilon}_{i t}\right)$ and change in the residual $\left(\Delta \hat{\varepsilon}_{i, t-i}\right)$ such that:

$$
I_{t}=\left\{\begin{array}{l}
\text { if } \hat{\varepsilon}_{i t-1} \geq 0 \\
\text { Oif } \hat{\varepsilon}_{i t-1}<0
\end{array}\right.
$$




$$
I_{t}=\left\{\begin{array}{l}
\text { if } \Delta \hat{\varepsilon}_{i t-1} \geq 0 \\
\text { Oif } \Delta \hat{\varepsilon}_{i t-1}<0
\end{array}\right.
$$

In Equation 3, the least squares estimates of $\rho_{1}$ and $\rho_{2}$ is based on the threshold autoregressive methods proposed by Tong (1983) and have an asymptotic multivariate normal distribution. The system of Equations 3 and 4 is known as the threshold autoregressive (TAR), and the combination of Equations 3 and 5 is known as the momentum threshold autoregressive (M-TAR). These two models are constructed using the original cointegration regression in equation 1.

The next step is to examine asymmetric cointegration relationship between the variables starting from the long-run regression in (1) for real investment indicator and determining whether this indicator and trade openness are cointegrated in the TAR and M-TAR models. We test the null hypothesis of no cointegration against the alternative of cointegration with asymmetry, where the null of $\rho_{l}=\rho_{2}=0$ is examined using an F-test of the joint hypothesis. However, the F-statistic has non-standard distribution and the critical values are tabulated by Enders and Siklos (2001) and called, $\Phi$ and $\Phi^{*}$, for the TAR and M-TAR models, respectively (Note 2).

Alternatively, t-statistics obtained from the point estimates of both $\rho_{1}, \rho_{2}$ are considered as the second method to test the hypothesis of no cointegration. This test is called the t-max test and it is based on reporting the most negative t-value associated with either $\rho_{1}$ or $\rho_{2}$ in (3). The negative sign of t-values associated with both $\rho_{1}, \rho_{2}$ are considered as the necessary conditions for convergence. Obviously, if the t-value on either $\rho_{1}$ or $\rho_{2}$ is positive, we would not reject the null and the F-test loses its validity (as it is a two-sided test), see Harris and Sollis (2003).

In this paper, we are testing for the presence of uncovered asymmetric cointegration. The E-G test, implemented in most of the previous empirical studies, is considered as a special case of the threshold cointegration test. The adjustment of the error term is asymmetric when variables are threshold cointegrated, where the adjustment is $\rho_{I}$ if the real investment indicator lagged one period $L R I_{i-1}$ is above its long-run equilibrium $\left(\beta_{0}+\beta_{1} L T O_{t}+\right.$ $\left.\beta_{2} L X_{i t}\right)$ in (1), and $\rho_{2}$ if $L R I_{i-1}$ is below. If $\rho_{l}=\rho_{2}$ in (3) adjustment is then symmetric (equal) and the E-G is a special case of (3) (Shen et al., 2007) and Enders and Siklos (2001).

\section{Empirical Results and Analysis}

To examine the potential asymmetric cointegration relationship between real investment, trade openness, and other variables, we first used the E-G test (see Table 1). We extend our research taking into account the possibility of having an asymmetric cointegration relationship among variables, employing Enders and Siklos's (2001) TAR model. The threshold value is set to be 0 .

Table 1. Stationarity test of the residual

\begin{tabular}{crc}
\hline \multicolumn{2}{c}{ Null Hypothesis: $\hat{\varepsilon}_{t}$ has a unit root } \\
\hline \multicolumn{2}{c}{ Indicator } & LRI ( Test-Statistic) \\
\hline \multicolumn{2}{c}{ Augmented Dickey-Fuller test statistic } & $\mathbf{- 3 . 5 7 4}$ \\
\hline \multirow{2}{*}{ Test critical values: } & $1 \%$ level & -3.627 \\
& $5 \%$ level & -2.946 \\
& $10 \%$ level & -2.612 \\
\hline
\end{tabular}

If we find evidence of asymmetric cointegration, we then continue our analysis by estimating the ECM including two adjustment coefficients to allow for asymmetric adjustment. The results of estimation of threshold cointegration relationships between real investment and trade openness are illustrated in Table 2. As we mentioned previously, Equation 3 represents the TAR model, along with Equation 4, of the disequilibrium errors for the model. Both F-statistic and t-Max are reported for the error equation. We use the critical values tabulated by Wane et al. (2004) for the test as they have extended the critical values of $\Phi$ and $\Phi^{*}$ for the null hypothesis of no cointegration with asymmetric adjustment for up to five variables with different sample sizes.

Table 2 reports the results from threshold cointegration analysis for the model. The test is conducted by using both F-statistic and t-Max. It is found that there is no asymmetric cointegration between trade openness and real investment as shown in model (1) since the $\Phi$ statistic for the null hypothesis $\rho_{1}=\rho_{2}=0$ is 8.075 which in less than the $5 \%$ critical value and we therefore cannot reject the null hypothesis of no asymmetric cointegration at $5 \%$ level of significance. 
Table 2. Asymmetric Cointegration Test (TAR and M-TAR) Model

\begin{tabular}{|c|c|}
\hline Models and Variables & Estimates \\
\hline $\begin{array}{l}\frac{\text { Model } 1}{4 \text { Variables }}(L R I, L T O, L Y, U C C) \\
\Phi\end{array}$ & $\hat{\varepsilon}_{1, t}=0.711 I_{t} \hat{\varepsilon}_{1, t-1}+0.492\left(1-I_{t}\right) \hat{\varepsilon}_{1, t-1}+u_{1, t}$ \\
\hline $\begin{array}{l}\frac{\text { Model } 2}{4 \text { Variables }}(L R I, L T O, L Y, U C C) \\
\Phi^{*}\end{array}$ & $\hat{\varepsilon}_{1, t}=-0.482 I_{t} \hat{\varepsilon}_{1, t-1}-0.729\left(1-I_{t}\right) \hat{\varepsilon}_{1, t-1}+u_{1, t}$ \\
\hline
\end{tabular}

In addition, we have failed to detect asymmetric cointegration between trade openness indicator and real investment as reported in model (2). F-statistics and t-Max calculated statistics are substantially smaller than their corresponding critical values indicating that the null hypothesis cannot be rejected at any level of significance which implies that the cointegration with asymmetric adjustment does not exist among these series. Therefore, neither symmetric nor asymmetric adjustments are found between trade liberalization and real investment in the Jordanian case.

\section{Conclusion}

This paper empirically examines the long-run equilibrium relationships between real investment and the level of trade openness in Jordan; using cointegration tests assuming asymmetric adjustments. Earlier study (Al-Tarawneh \& Al-Assaf, 2014), investigated the relationship between trade openness and real investment in Jordan, fond strong evidence on the presence of a long-run stable investment function. However, the results did not provide any information whether this relationship is symmetric or asymmetric. This study extends the standard Engle-Granger Cointegration tests, used in the previous empirical work, by testing for the presence of asymmetric cointegration among data. We failed to reject the null hypothesis of no cointegration with threshold at a conventional level of significance. The results obtained show that there is no evidence of presence of asymmetric pattern in the relationship; then the real investment does not respond asymmetrically to changes in trade liberalization.

\section{References}

Al-Assaf, G. (2014). Testing for Asymmetric Cointegration Relationship between Banking Sector Development and Trade Openness: Evidence from Jordan. Dirasat, Administrative Sciences, 41(2), 497-507. http://dx.doi.org/10.12816/0007485

Al-Tarawneh, A., \& Al-Assaf, G. (2014). Trade openness and real investment in Jordan: An ARDL bound testing approach. Jordan Journal of Economics Sciences, 1(1), 79-94. http://dx.doi.org/10.12816/0003517

Anoruo, E., Saten, K., \& Bill, D. (2007). A Co-integration Analysis of Investment Output Ratio in Bangladesh. MPRA, working paper, No. 19338.

Cook, S. (2007). Threshold adjustment in the long-run relationship between stock prices and economic activity. Applied Financial Economics Letters, 3(4), 243-246. http://dx.doi.org/10.1080/17446540601018931

Du Toit, C., \& Elna, M. (2004). A neoclassical investment function of the South African economy. Economic Modelling, 21, 647-660. http://dx.doi.org/10.1016/j.econmod.2003.09.004

Enders, W. (2004). Applied econometric time series. Technometrics, John Wiley \& Sons, USA.

Enders, W., \& Granger, C. W. J. (1998). Unit-root tests and asymmetric adjustment with an example using the term structure of interest rates. Journal of Business \& Economic Statistics, 16(3), 304-311.

Enders, W., \& Siklos, P. L. (2001). Cointegration and threshold adjustment. Journal of Business and Economic Statistics, 19(2), 166-176. http://dx.doi.org/10.1198/073500101316970395

Engle, R. F., \& Granger, C. W. J. (1987). Co-integration and error correction: Representation, estimation, and testing. Econometrica: Journal of the Econometric Society, 55(2), 251-276. http://dx.doi.org/10.2307/1913236 
Harris, R. I. D., \& Sollis, R. (2003). Applied time series modelling and forecasting. England: J. Wiley and Sons.

Heim, J. J. (2008). The Investment Function: Determinants of Demand for Investment Goods. Rensselaer, working papers in economics, NY.

Ismihan, M., Metin-Ozcan, K., \& Aysit, T. (2005). The Role of Macroeconomic Instability in Public and Private Capital Accumulation and Growth: The Case of Turkey 1963-1999. Applied Economics, 37, $239-251$. http://dx.doi.org/10.1080/0003684042000286115

Laixiang, S. (1998). Estimating Investment Functions Based on Co-integration: The Case of China. Journal of Comparative Economics, 26, 175-191. http://dx.doi.org/10.1006/jcec.1997.1501

Lardic, S., \& Mignon, V. (2008). Oil prices and economic activity: An asymmetric cointegration approach. Energy Economics, 30(3), 847-855. http://dx.doi.org/10.1016/j.eneco.2006.10.010

Oladipo, O. S. (2011). Does trade liberalization cause long run economic growth in Mexico? An empirical investigation. International Journal of Economics and Finance, 3, 63-74. http://dx.doi.org/10.5539/ijef.v3n3p63

Shafik, N. (1992). Modelling Private Investment in Egypt. Journal of Developing Economics, 39, $263-277$. http://dx.doi.org/10.1016/0304-3878(92)90040-G

Shen, C. H., Chen, C. F., \& Chen, L. (2007). An empirical study of the asymmetric cointegration relationships among the Chinese stock markets. Applied Economics, 39(11), 1433-1445. http://dx.doi.org/10.1080/00036840600606302

Tong, H. (1983). Threshold models in non-linear time series analysis. Springer-Verlag, New York. http://dx.doi.org/10.1007/978-1-4684-7888-4

Wane, A., Gilbert, S., \& Dibooglu, S. (2004). Critical Values of the Empirical F-Distribution for Threshold Autoregressive and Momentum Threshold Autoregressive Models. Department of Economics, Southern Illinois University, USA.

\section{Notes}

Note 1. Unit root tests and descriptive statistics results are presented in Tables A and B, respectively, in the appendix of this paper.

Note 2. Enders and Siklos (2001) have conducted two Monte Carlo experiments to test the null of no cointegration against the alternative of cointegration with threshold adjustment. In the first test (TAR), the value of $\tau$ is set equal to 0 , and in the second test (M-TAR), $\tau$ is unknown.

\section{Copyrights}

Copyright for this article is retained by the author(s), with first publication rights granted to the journal.

This is an open-access article distributed under the terms and conditions of the Creative Commons Attribution license (http://creativecommons.org/licenses/by/3.0/). 